N. Y. Kaliuzhnova

\title{
INSTITUTES OF REGIONAL DEVELOPMENT AND COMPETITIVENESS IN THE CONDITIONS OF MODERNIZATION
}

This paper discusses the problem of identifying institutions that influence the development of the regions. The role of institutions in the concept of regional competitiveness is reviewed. Institutional systematization of institutions for regional development is implemented. Quantitative analysis results of the influence on indicators of regional development by a series of institutions are published.

\section{Problem definition}

The propositions «institutions matter» and «institutions are of importance» have now become a common thesis in scientific papers on economy, both western and Russian. The institutions are characterized as a basis for economic growth and competitiveness of countries and regions. The economy is competitive in the whole world if economic institutions and policies of the country provide steady and rapid economic growth.

A point of view has been explicated that the institutions are the brake of Russian economy's regional development; the insufficiency of existing empirical research on current subject is also mentioned (N.V. Zubarevich) [1]. In this case, namely the institutional side should be the top priority in the analysis of regional development strategies modernization. We believe that there is lack not only of empirical but also of theoretical analysis of the institutions that influence regional development.
In order to identify which institutions are important and what kind of impact they have, it is necessary to identify those institutions and to measure their impact on regional development. The question remains if we should create new institutions for development or lift restrictions on regional development imposed by existing institutions.

\section{Institutions in the concept of regional competitiveness}

The theory of economic mainstream does not consider the regions as economic entities that make independent economic decisions. In the planned economy the regions also weren't economic subjects, the role of the regions was to take stock of the state interests in the areas of business location; this role was further discussed in the regional economy.

In the so-called new political economy - the institutional branch of economical theory - the regions are already considered as a quasi-states and quasi-businesses and, thereafter, as the participants of the competitive processes. This interaction of aggregated economic subjects happens at the mesolevel of economic system.

Consideration of the Russian economy not as homogenous but as multiregional organism functioning on the basis of vertical and horizontal interactions (A. Granberg) [9] in which the relationship between the regions is competitive in nature 
(G.A. Untura, R. I. Shniper) [7], became, in our view, an important step in approaching positions of economic theory and regional economics and development.

In our works in 2003-2004 [3, 4, 10] the concept of competitive paradigm of the region was proposed in which the region is considered as a subject of economic management and competition in the light of globalization, regionalization and institutional conditions of the early 2000's.; a methodology for the analysis of regional competitiveness and a multi-factor index of regional competitiveness were developed, indices and dynamics of the competitive positions of 89 Russian regions for the years 1995, 1998 and 2000 were calculated. The analysis showed that the development of Russian regions goes in the opposite direction to the structural dynamics of the global economy as a whole, the share of the extractive sector is growing and this trend continues in 2000-2007.

We should note that the approach of regional competitiveness has not been clearly perceived positively in the past times. In a review of a paper by N.Y. Kaliuzhnova [8] V. N. Leksin in the overall positive assessment criticized the possibility of considering a region as a business entity and interregional competition was described as resources pulling-over from one region to another1.

At the same time, the concept of competitive paradigm has found a significant number of supporters and the theme of interregional competitiveness is developing in different scientific schools. Today, there arefour4 main areas of research in these topics: rating system development for the competitiveness of regions, cluster approach to ensuring the competitiveness of regions, regional innovation system, and analysis of intangible factors of regional competitiveness.

The most actively developing are the first two areas - calculation and cluster subject matters. Many methods for calculating an index of regional competitiveness are suggested: more or less known, depending on the capabilities of regular monitoring and summary indices calculation of regional development performance as well as access to scientific and media information.

\footnotetext{
${ }^{1}$ V. N. Leksin: «In general case, the victory in the competition between regions $\mathrm{A}$ and $\mathrm{B}$ can only mean that the population and capitals of the conquered region begins moving from the territory of A to the territory of $\mathrm{B}$, once and for all pushing the conquered one into the prolonged depression» $[8, \mathrm{p} .88]$.
}

Our proposed methodology of regional competitiveness index reflects groups of indicators:

1) economic performance of regions;

2) factorial;

3) infrastructural;

4) institutional;

5) informational competitive advantages of regions.

Institutional benefits were assessed by two indicators - the number of small enterprises per 1000 people and regional budget expenditures per capita. The choice of these indicators of institutions is explained by the possibilities of statistics and the fact that small business development is an indicator of economic freedom while and the index of budgetary capacity is the result of formal and informal negotiations power of the regions. Today, we believe that there is need for adjustment of institutional environment indicators. However, in many regional competitiveness indexes proposed by other authors, the indicators of the institutional regional environment are not included at all or are not justified. This is due just to the complexity of defining and measuring the institutions that affect the competitiveness of regions.

But the insidiousness of the institutional problem is that the state of the institutional environment determines whether the concept of regional competitiveness at a particular stage of the country's development is working or not. This concept is based on the approach to the region as an economic entity, which can and must prove its right to profits with its economic decisions and results rather than capital status, proximity to the Kremlin or informal institutional practices of receiving transfers. Not every region can become a business entity and it does not depend on the presence of a single owner in the region but on the degree of regional elite's maturity and their consolidation. At the same time a competitive environment is necessary for the economic competitiveness of regions, absence of individual regions monopoly; there is a need for institutions that provide regional availability of resources and opportunity to make important economic decisions.

The dynamics of institutional environment in inter-regional competition had three pronounced stages between 1991 and 2010. The first one development regional sovereignty (1991-1998), the second one - growth of centralization (19982005) with the abolition of governors election, the introduction of governors appointment system, and its further strengthening (2005-2008) on the basis 
of increased redistribution processes. The stake on the concept of supporting regions in this period was combined with the development of so-called manual control. There is a concentration of economic resources in the hands of the federal center that is not allowing regions to earn money and develop on their own, besides that it is serving as a mechanism of political pressure on the rich territories. In 2008 the former head of the Ministry of Regional Development D. N. Kozak acknowledged the complete collapse of the regional policy based on principles of centralization.

In 2009-2010 the idea of strategic planning in the regions was developed. The creation of a new regional policy concept is officially happening; this preserves the appointment of regional heads and the system of so-called manual mode «fireguard solutions» for regional problems, allocation of transfers depending on the lobbying capacity and persistence of governors and the subjective preferences of the President and Prime Minister. We have to agree that there is actual absence of clear and understandable institutions of making decisions on the regions which do not ensure their economic independence.

Returning to the criticism of the approach to regional competitiveness made by V.N. Leksin, we note that, in our opinion today's regional competi- tiveness is important not in terms of lack of a united owner in the region but from the standpoint of the current lack of effective institutional interregional competition framework. An institutional trap is created on the federal level of rules which allow governors solving current problems to some extent and do not allow them implementing of the proclaimed policy objectives of improving the regional competitiveness. Furthermore, these competitiveness ratings do not reflect the effect of competitive (i. e. economic) positions of the regions; in fact these ratings display quasi-competitiveness. The problem of institutions becomes the central problem of the regional competitiveness concept.

\section{Institutional approach to regional studies}

Regional research institutions are regarded as one of the factors that influence the differentiation and development of the regions. However, there are different formulations of the institutions, their composition and characteristics. Table 1 shows the main existing approaches to the concept of regional development institutions.

In our view, the range of problems and subject matter of regional development institutions includes institutions of different economic system levels that influence the development of regions. These are

Table 1

Regional development institutions

\begin{tabular}{|l|l|}
\hline \multicolumn{1}{|c|}{ Institution name / source } & \multicolumn{1}{c|}{ Description of institution(s) } \\
\hline $\begin{array}{l}\text { Institution of capital status. } \\
\begin{array}{l}\text { Institution of special economic zones. } \\
\text { Institution of internal offshore zones. }\end{array}\end{array}$ & $\begin{array}{l}\text { The whole big business is concentrated in the capital } \\
\text { Conditions of special tax benefits } \\
\text { Conditions of regional tax benefits } \\
\text { Foundations and organizations }\end{array}$ \\
\hline $\begin{array}{l}\text { Regional development institutions: the Agency of strate- } \\
\text { gic regional development. Venture capital and guarantee } \\
\text { funds. Consulting and counseling centers. Institutions } \\
\text { of small business development [15] }\end{array}$ & $\begin{array}{l}\text { Non-profit organizations created specifically in the regions to } \\
\text { analyze the possibilities of the region, to attracting public and } \\
\text { private financial resources for development of new markets and } \\
\text { implementation of innovations }\end{array}$ \\
\hline $\begin{array}{l}\text { Complementary institutions of regional development } \\
\text { [12, 17] }\end{array}$ & $\begin{array}{l}\text { Institutions as catalysts of innovational economic growth, as } \\
\text { structures compensating the duration of regional institutional } \\
\text { framework formation and effective tools of state regional industrial } \\
\text { policy implementation }\end{array}$ \\
\hline $\begin{array}{l}\text { Municipal development fund. Regional financial reform } \\
\text { fund. Free economic zones [2] }\end{array}$ & $\begin{array}{l}\text { Special funds and programs created for the regional development } \\
\text { policy }\end{array}$ \\
\hline Socio-entrepreneurial corporations [16] & $\begin{array}{l}\text { Special organizations managing state assets at the local level for the } \\
\text { regional development }\end{array}$ \\
\hline $\begin{array}{l}\text { Scientific and technological parks and business incuba- } \\
\text { tors [14] }\end{array}$ & $\begin{array}{l}\text { Centers of high-technology companies concentration around the } \\
\text { major universities and research institutes, with the active work } \\
\text { of private businesses and governmental support stimulating the } \\
\text { development }\end{array}$ \\
\hline $\begin{array}{l}\text { Institutions of development at the federal level. Federal } \\
\text { development institutions at the regional level. Regional } \\
\text { development institutions proper [13] }\end{array}$ & $\begin{array}{l}\text { The sum total of established and state-funded special organizations } \\
\text { that co-finance commercial projects of high economic or social } \\
\text { significance }\end{array}$ \\
\hline
\end{tabular}

Source: compiled by the author. 
macro-level institutions (in fact meso-level), micro level (for example, the institute of authorities' or corporations' corporate culture), and finally, nanolevel institutions (for example, the institute of selfemployment). We should also mark institutions not only by levels but also by the type of rules regulated by these institutions at every level. Finally, we should divide functioning institutions and development institutions proper at every level of economy. Systematization of institutions based on different qualitative grounds is presented in table. 2 .

In the approaches to the institutions of regional development the focus is set on the creation of new institutional forms - foundations, organizations and structures stimulating separate areas of regional economy. But not only these forms but also the quality of general economic institutions influences the regional development.

\section{Assessment of the institutions}

The results indicators of certain institutional conditions actions are commonly used for the institutions assessment: for example, the quality of institutions and the development of small businesses, the estimated rates of small business development, the indicators of innovative institutions are a number of

Table 2

Typology of institutions

\begin{tabular}{|c|c|c|c|c|}
\hline Criterion for highlighting & \multicolumn{4}{|c|}{ Types of institutions / examples } \\
\hline \multirow{2}{*}{ Degree of formality } & \multicolumn{2}{|l|}{ Formal } & \multicolumn{2}{|l|}{ Informal } \\
\hline & \multicolumn{2}{|l|}{ Constitution. Laws } & \multicolumn{2}{|l|}{ Lobbying, corruption } \\
\hline \multirow{2}{*}{ Degree of compulsion } & \multicolumn{2}{|l|}{ Hard } & \multicolumn{2}{|l|}{ Soft } \\
\hline & \multicolumn{2}{|c|}{ Judicial system. Clannish / tribal system } & \multicolumn{2}{|l|}{ Credit and tax system } \\
\hline \multirow[b]{2}{*}{ Type of regulated relations } & Political & Economical & Social & Interpersonal \\
\hline & $\begin{array}{l}\text { State form of } \\
\text { government - both } \\
\text { formal and real. The } \\
\text { elections }\end{array}$ & $\begin{array}{l}\text { Delineation of } \\
\text { property rights on all } \\
\text { kinds of resources }\end{array}$ & $\begin{array}{l}\text { Confidence in } \\
\text { institutions. Social } \\
\text { capital }\end{array}$ & $\begin{array}{l}\text { Interpersonal trust of } \\
\text { the politicians }\end{array}$ \\
\hline Type of rules & Coordination & $\begin{array}{l}\text { Distribution of costs } \\
\text { and benefits }\end{array}$ & Cooperation & Us-them / friend-or-foe \\
\hline On macro-level & $\begin{array}{l}\text { Regional, industrial } \\
\text { and structural policy }\end{array}$ & $\begin{array}{l}\text { Distribution of budgets } \\
\text { and powers }\end{array}$ & $\begin{array}{l}\text { Federal foresight. Civil } \\
\text { society }\end{array}$ & $\begin{array}{l}\text { Social capital. Political } \\
\text { elections }\end{array}$ \\
\hline On meso-level & $\begin{array}{l}\text { Regional development } \\
\text { strategies, programs of } \\
\text { separate spheres }\end{array}$ & $\begin{array}{l}\text { Investment programs. } \\
\text { State order. Special } \\
\text { funds }\end{array}$ & $\begin{array}{l}\text { Clusters, networks. } \\
\text { Region. Foresight. } \\
\text { Private-state } \\
\text { partnership } \\
\end{array}$ & $\begin{array}{l}\text { Social capital. Norms of } \\
\text { reciprocity }\end{array}$ \\
\hline On micro-level & Corporate planning & Corporate governance & Informal norms & Corporate culture, trust \\
\hline Level of regulated relations & $\begin{array}{l}\text { Federal institutions of } \\
\text { general regulation }\end{array}$ & $\begin{array}{l}\text { Federal institutions of } \\
\text { regional regulation }\end{array}$ & Regional institutions & Local institutions \\
\hline & $\begin{array}{l}\text { Constitution. Laws. } \\
\text { Development bank. } \\
\text { Investment fund }\end{array}$ & $\begin{array}{l}\text { Housing reform fund. } \\
\text { Special economic } \\
\text { zones }\end{array}$ & $\begin{array}{l}\text { Regional funds. } \\
\text { Programs and agen- } \\
\text { cies of development }\end{array}$ & $\begin{array}{l}\text { Reciprocal lending } \\
\text { society. Homeowners } \\
\text { association }\end{array}$ \\
\hline Purpose of regulation & \multicolumn{2}{|c|}{ Institutions of functioning } & \multicolumn{2}{|c|}{ Institutions of development } \\
\hline On federal level & \multicolumn{2}{|c|}{$\begin{array}{l}\text { Constitution and legislation. Budgetary and } \\
\text { tax system. Federal special-purpose programs. } \\
\text { Financial institutions }\end{array}$} & \multicolumn{2}{|c|}{$\begin{array}{l}\text { Investment fund of Russian Federation. } \\
\text { Development bank, Russian venture company. } \\
\text { Agency for housing mortgage lending. Russian } \\
\text { corporation of nanotechnologies. Housing re- } \\
\text { form fund. Rosselkhozbank. Rosagroleasing. } \\
\text { Foundation for promotion of small business in } \\
\text { the scientific-technical sphere. Russian fund for } \\
\text { information-communication technologies. The } \\
\text { law on special economic zones. Foresight }\end{array}$} \\
\hline On regional level & \multicolumn{2}{|c|}{$\begin{array}{l}\text { Regional legislation. Distribution of budgets. } \\
\text { Regional planning and projection }\end{array}$} & \multicolumn{2}{|c|}{$\begin{array}{l}\text { Strategies and programs of development. } \\
\text { Business incubators. Regional development } \\
\text { agencies. Funds supporting small business } \\
\text { and promoting venture investments, venture } \\
\text { funds. Development banks. Consulting centers. } \\
\text { Regional foresight }\end{array}$} \\
\hline
\end{tabular}

Source: compiled by the author. 
Table 3

Assessment of the institutions in the Global competitiveness index (GCI)

\begin{tabular}{|c|c|c|}
\hline № & Types and indicators of the institutions & Region \\
\hline A & Public institutions & \\
\hline \multirow[t]{3}{*}{1} & Property right & \\
\hline & Property rights & \\
\hline & Intellectual property protection & \\
\hline \multirow[t]{3}{*}{2} & Ethics and corruption & \\
\hline & Diversion of public funds & + \\
\hline & Public trust in politicians & + \\
\hline \multirow[t]{3}{*}{3} & Improper influence & \\
\hline & Judicial independence & + \\
\hline & Favoritism in making decisions & + \\
\hline \multirow[t]{6}{*}{4} & Governmental inefficiency & \\
\hline & Wasteful governmental spending & + \\
\hline & Burden of governmental regulation & + \\
\hline & $\begin{array}{l}\text { Effectiveness of the legislative framework in } \\
\text { setting disputes }\end{array}$ & \\
\hline & $\begin{array}{l}\text { Effectiveness of the legislative framework in } \\
\text { complex settlements }\end{array}$ & \\
\hline & Transparency of governmental policy & + \\
\hline \multirow[t]{5}{*}{5} & Security / safety & \\
\hline & Business costs in the context of terrorism & + \\
\hline & Business costs in the context of crime & + \\
\hline & Organized crime & + \\
\hline & Reliability of police services & + \\
\hline \multirow[t]{7}{*}{ B } & Private institutions & \\
\hline & Corporate ethics & + \\
\hline & Ethical behaviour of business & + \\
\hline & Statements, accountability & \\
\hline & Strength of auditing and accounting standards & \\
\hline & Effectiveness of corporate governance & + \\
\hline & $\begin{array}{l}\text { Protecting the interests of minority } \\
\text { shareholders }\end{array}$ & \\
\hline
\end{tabular}

Source: The Global Competitiveness Report. World Economic Forum, Executive Opinion Survey 2008, 2009 (translated by the author).

innovations. At the same time we must bear in mind that small business development is associated not only with regional institutional incentives but also with the possibilities of local demand, and innovations are associated with the presence of regional innovation infrastructure.

Let's review the kinds of institutions ranked in the Global competitiveness index (GCI) of countries, and distinguish those that can be identified at the regional level (see table 3). Some of them can be studied using existing databases while others require further expert studies.

\section{The influence of institutions on regional development}

As a practical application we reviewed several institutions and their impact on such indicators of competitiveness and regional development as growth regions of the gross regional product (GRP) and the size of GRP per capita.

To analyze the impact of institutions on the regional growth we put forward four hypotheses:

1. Hypothesis on the impact of informal corruption institution (which is given great importance in institutional indicators of IEF) on economic growth.

2. Hypothesis on the impact of entrepreneurship institution on regional growth.

3. Hypothesis on the impact of institutional trust on the regional economic growth.

4. Hypothesis on the impact of specially created development institutions of regional development indicators.

To verify the first hypothesis it was necessary to confirm or disprove the dependence of regional economic growth on the level of corruption and show how the state of corruption affects economic growth. We used the Corruption Perception Index (CPI) as an indicator of corruption [11] (index 10 means almost no corruption, index 0 - the highest level of corruption). Regional indices of corruption according to the research of TI-Russia and INDEM Foundation were published just once in 2002; the data is available for 40 Russian regions only. Therefore, this problem has been tested primarily at the level of former socialist countries bloc. The sampling included 12 countries in Eastern Europe and CIS including Russia. The sampling contains countries with both relatively high and relatively low CPI - the countries most similar to Russia in the everyday problems and level of development. An average growth rate of per capita volume of GDP for almost 20 years is an indicator of economic growth. Table 4 shows the details: the average rate of economic growth $-Y(\%)$ and average values of the CPI $-X$ (units).

Functions of linear and quadratic regression were built

The derived linear regression function:

$$
y=0,626+1,590 x \text {. }
$$

Quadratic regression function:

$$
y=-1,0381 x^{2}+9,2532 x-12,288 .
$$

In a linear regression function, the share of economic growth variation is attributable to the changes

in the level of corruption, $\hat{R}_{y . X}^{2}=0,434$, т. e. $43.4 \%$ 
Table 4

Corruption Perception Index (CPI) by countries, 1990-2007

\begin{tabular}{|l|c|c|}
\hline \multicolumn{1}{|c|}{ Country } & $\boldsymbol{X}_{\boldsymbol{i}}(\mathbf{C P I})$ & $\boldsymbol{Y}_{\boldsymbol{i}}(\mathrm{GDP}$, average, annual $)$ \\
\hline Azerbaijan & 1,98 & 2,1 \\
\hline Kazakhstan & 2,39 & 6,2 \\
\hline Russia & 2,48 & 5,18 \\
\hline Ukraine & 2,51 & 3,33 \\
\hline Moldavia & 2,67 & 2,1 \\
\hline Rumania & 3,08 & 7,7 \\
\hline Belarus & 3,31 & 5,58 \\
\hline Bulgaria & 3,75 & 5,9 \\
\hline Slovakia & 4,03 & 9,03 \\
\hline Poland & 4,18 & 10,1 \\
\hline Hungary & 4,99 & 9,1 \\
\hline Czech Republic & 5,46 & 6,1 \\
\hline
\end{tabular}

of variations are explained by changes in the level of corruption and the remaining $56.6 \%$ by the influence of other factors. The linear regression function allows us to establish that the increase in CPI by 1 unit leads to economic growth of $1.59 \%$ per year.

As the international experience shows, it is very difficult to conquer corruption completely because the reduction of corruption after a certain level is fraught with escalating costs and, consequently, a decrease in economic growth. To analyze the optimal size of corruption in connection with economic growth we consider the quadratic regression function more suitable. In a quadratic function, the share of economic growth variation could be explained by the change in the level of corruption $\hat{R}_{y . X}^{2}=0,611$, T. e. $61.1 \%$ of variations are explained by changes in the level of corruption. Both models are statistically significant at $\alpha=0,1$.

Both linear and quadratic regression functions indicate that the increase of the CPI (and thus, reducing corruption) has a positive effect on economic growth. However, the quadratic regression function reflects the dynamics of CPI impact on economic growth more convex and brings out the fact that the positive impact of the CPI growth on the economic growth is possible only up to a certain level. The maximum growth of the CPI increase is $8.33 \%$ at the level of $\mathrm{CPI}=4.46$. CPI values $>4.46$ would already lead to a decrease in economic growth. When $x<3.69$ quadratic regression function gives even greater effect than the linear regression function. For values of $x$ in the range between $(3.69,4.46)$, there is a slowdown in the economic growth and improvement of the situation with corruption. Thus, the optimum point $(x, y)=(4.46 ; 8.33)$ represents the maximum possible positive effect of reducing corruption on economic growth. The obtained regression function findings allow us to estimate with other conditions remaining the same the value of economic growth at any level of the CPI and do the conclusion that the state of corruption significantly affects national economic growth of countries and reduction of corruption within certain optimal limits will increase economic growth tempo.

Next, we examined the relationship of the CPI in 40 Russian regions according to a study by the INDEM Foundation in 2002 and indicators of economic development in these regions. The analysis showed no statistically significant relationship in CPI neither with growth rates nor GDP per capita, neither in 2002 nor in 2003 (assuming the deferred effect of corruption). Narrow time horizon for measuring the CPI by region (one year) gives an opportunity to make full conclusions. It can be assumed that the lack of serious impact of the regional corruption perception indexes is due to the fact that major corrupt deals are carried out primarily at the federal level and are related to the activities of major players at the regional level - corporations that have a significant effect on the size of the gross regional product.

The next hypothesis, on the influence of the small business (SB) institution on regional development, for which we studied the connection parameters between SB growth rates and regional GRP volumes. Regression analysis was conducted according to the data on the development of Russian regions in 2008 (excluding Moscow and St. Petersburg). This analysis showed no significant relationship between indicators of MP development (such as the number of small businesses, the turnover of small enterprises, the average number of employees) and the volume and GRP growth rate. The only indicator of positively influencing the GRP volume is the turnover of small businesses but it has no significant statistical influence. Regression equation of the regional GRP size from the SB turnover size can be explained only by $36.73 \%$ dispersion of the effective indication; the share of the rest is $63.27 \%$ of its dispersion. This can be explained by the fact that the size of small business in Russia is still not sufficient for a significant impact on GRP growth rates and GRP volumes.

On the question of trust and economic growth interconnection (third hypothesis), we refer to findings of other authors. In a study [18] it was shown that trust by itself is positive and has significant im- 
pact on economic growth, whenever it is included in the regression of economic growth with the measurement of formal institutions or social distance.

There is no data which is needed to measure the quantitative impact of trust in economic growth in all Russian regions. Our studies in Irkutsk region showed a negative trend of institutional trust in virtually all public institutions $[5,6]$, especially to institutions of regional - and even more - local authority. Furthermore, the increase in institutional trust can be regarded as an important reserve of economic growth boost in the region.

The analysis of the influence of so-called development institutions (which were formed in 20082010) on the development indicators of the regions (the fourth hypothesis) was based on the data about the size of the funds established in 2008-2009 to support small and medium-sized businesses in the regions, regional mortgage funds, regional venture capital funds and funds investing into special economic zones [13]. The mentioned funds are examples of specially created regional development institutions.

We have analyzed the regressive interconnections between the size of these funds and related indicators of the processes for which stimulation they were created. Namely, the performance of small business development, housing construction, introduction of new products and capital investments growth in the regions according to the «Regions of Russia» Yearbook for 2010.

The linear regression function of changes in the number of small businesses depending on the growth of appropriations for the development of small and medium-sized businesses showed that in $200974.3 \%$ of small business amount variations are attributable to the changes in volume of SB development assets while the remaining $25.7 \%$ is attributable to the influence of other factors. In the quadratic regression this percentage is even higher $-78 \%$. Thus, we can conclude that the regional funds to promote small and medium businesses do quite effectively perform their role - they help to increase the number of small businesses in the region. At the same time, as we mentioned earlier, the contribution of small business into the regional development indicators is statistically insignificant yet.

Institutions for regional development aimed at stimulating housing construction are represented by the Agency for housing mortgage lending (AHML) and regional mortgage funds. The state implements programs for affordable housing and provides sup- port for the mortgage market through AHML. Most of the regional mortgage funds are working on a basis of partnership agreements with AHML.

The effectiveness of regional mortgage funds can be assessed by indicators of housing in the regions. Evaluation of relationship between the amounts of apartments put into service from mortgage lending volumes by region in 2009 in a linear regression function showed that only $33.2 \%$ of variations of housing are explained by the change in volume of mortgage lending, and the remaining $66.8 \%$ - by the influence of other factors. The resulting regression function allows us to establish that the increase in mortgage lending volume through the institutions of regional development by 1 million rubles leads to an increase in the amount of apartments put into service by $9.78 \%$. In a quadratic function $37.3 \%$ of variations are explained by the change in volume of mortgage lending, and the remaining $62.7 \%$ - by the influence of other factors. These connections are statistically significant and we can suggest that the dependence of the amount of apartments put into service in the region on the mortgage lending through institutions of regional development was confirmed and regional mortgage funds actually support the growth of housing performance in the region.

Special economic zones as an institution for regional development are the limited areas with special legal status and favorable conditions for national businesses and entrepreneurs. The main task of the special economic zones is the creation of new enterprises or other kinds of economic activity in the region. The state offers tax incentives to the residents of special economic zones and helps to attract capital into the region. The influence of special economic zones on investment activity in the regions was examined by analyzing the dependence of investment in fixed assets in the region on the number of funds raised through the institution of special economic zones.

Regressive analysis of the influence of the attracted funds volume through the special economic zones on the investment volume indicator into fixed regional capital (where these institutions are available) showed no statistically significant interconnection between these indicators. The corresponding conclusion according to the 2009 data is that the special economic zones have not had a significant impact on attracting investment into the regions.

Finally, the impact analysis of such an institution as the regional venture capital funds revealed 
that (according to 2009) there is no statistically significant association of innovative goods and services produced in the region during the year and the amount of money invested by regional venture capital funds.

Thus, the first results of work done by the development institutions show that the funds to promote small and medium enterprises and regional mortgage funds solve their problems quite successfully. The results of institutions' operations such as special economic zones and regional venture capital funds are small yet which can be explained both by the imperfection of the institutions and the possible long-term effect of their work.

In conclusion we should note that creation of so-called special regional development institutions without improving the quality of macroeconomic institutions, which affect regional development, is unlikely to give the desired effect for regional development.

\section{References}

1. Zubarevich N. V. Regional development and institutions / Expert channel «Open economy». [Electronic resource]. URL: http://opec.ru/1240639.html

2. Institutional measures for implementing the regional development strategy. Review of international experience // Region. Economics and sociology. 2007. № 3. P. 259-277.

3. Kaliuzhnova N. Y. Russian regions joining the competitive processes // Regional competitiveness. Theoretical and applied aspects / ed. Y. K. Perskiy, N. Y. Kaliuzhnova. M.: TEIS (MSU), 2003. $472 \mathrm{p}$.

4. Kaliuzhnova N. Y. Competitiveness of Russian regions in the context of globalization. M.: TEIS (MSU), 2003. 526 p.

5. Kaliuzhnova N. Y. Economy of distrust. Features and economic role of social capital in Russia. On the example of Irkutsk region. [Report on the grant of N. P. Fedorenko International scientific foundation]. Irkutsk, $2009.65 \mathrm{p}$.

6. Kaliuzhnova N. Y., Lokhova S. V. Social capital and trust in the regional context // Problems of economics and management: collected papers / Scient. ed. N. Y. Kaliuzhnova. Irkutsk: Irkutsk State University Publishing House, 2010. P. 311-322.

7. Competitive positions of the region and their economic evaluation: colected papers / Edited by G. A. Untura.
Novosibirsk: Institute of Economics and Industrial Engineering of the Siberian Branch of the RAS, 1997. 212 p.

8. Leksin V. N. Regional competitiveness phenomenon in the global economy. On the cycle of monographs by N. Y. Kaliuzhnova / Russian Economic Journal. 2005. № 4. P. 86-92.

9. A path into the XXI century: strategic challenges and prospects of the Russian economy / [Granberg A. G. et. al.] Edited by D. Lvov et. al. Moscow: OAO «Ekonomika» Publishing House, 1999. 793 p.

10. A region at the crossroads of East and West: globalization and competitiveness / [Kaliuzhnova N. Y. et. al.] Edited by Kaliuzhnova N. Y., Lidin K. L., Jacobson A. Y. M.: TEIS (MSU), 2003. 359 p.

11. Regional public foundation «Informatics for democracy»// INDEM-Anticorruption. [Electronic resource]. URL: http://www.indem.ru/russian.asp.

12. Romanova O. A. Industrial policy - the evolution of the implementation mechanism // Contemporary competitiveness. 2008. № 6.

13. Russian institutions of development. Regional aspect. / S. Volkov, M. Doronkin, A. Gorbunov et. al. // RA «Expert» official website [Electronic resource]. URL: http://www.raexpert. ru/researches/regions/ros_evolution/part3/

14. Scientific and technological parks and business incubators in the U.S. system of regional development // Herald of Chuvash University. 2010. № 2. P. 440-446.

15. Stepanova $\mathrm{V}$. A magnet for federal money // ExpertUral. 2008. № 1-2(312) (21 Jan.).

16. Suleymenova G. K. Socio-entrepreneurial corporations. Regional development institutions in the Republic of Kazakhstan // Journal of institutional research. 2010. Volume 2. № 2. P. 72-80.

17. Tatarkin A. I., Romanova O. A. Socio-entrepreneurial corporations. Regional institution of industrial policy and its implementation mechanism / Systemic approach // The Region's Economics. 2007. № 3.

18. Hart J. A. Rival Capitalist. International Competitiveness in the United States, Japan and Western Europe. Ithaca: Cornell University Press, 1992.

19. Zak P. J., Knack S. Trust and Growth // The Economic Journal. 2001. № 111. P. 295-321.

\section{UDC 338:91:339.137.22}

Keywords: institutions, development, competitiveness, institutional trust, corruption, small business development funds, venture capital funds, mortgage funds, special economic zones, regression relationship 